PART 2

The $\mathrm{E}$ and the Arctic Region 
Mar Campins Eritja - 9789004349179 Downloaded from Brill.com04/26/2023 02:35:47PM via free access 


\title{
Strengthening the European Union-Greenland's Relationship for Enhanced Governance of the Arctic
}

\author{
Mar Campins Eritja
}

\section{1 \\ Introduction}

Greenland (Kalaallit Nunaat: "the Country of the Greenlanders") is the largest island in the world, with an area of about 2.2 million square $\mathrm{km}$ (of which $80 \%$ is permanently covered by ice), more than $44,000 \mathrm{~km}$ of coastline, ${ }^{1}$ and a population density of 0.14 inhabitants per square $\mathrm{km}$ in the ice-free areas. ${ }^{2}$

Due to its location in the Arctic, Greenland, an autonomous territory still dependent on Denmark, has acquired a unique strategic relevance for the European Union (EU). In an international context where economic powers such as China or South Korea have expressed great interest in the Arctic and especially in the huge potential of natural resources, hydrocarbons and strategic minerals, the EU's presence in the region is undoubtedly connected with the need to strengthen its relationship with Greenland, a matter that is back into focus in the political debate.

This Chapter aims to describe the current legal framework concerning the relationship between Greenland and the $\mathrm{EU}$, as well as some of the reasons for the interest of the $\mathrm{EU}$ in Greenland with special attention to those specially related to the exploitation of hydrocarbons. To ensure the effectiveness of its collaboration with Greenland and, by extension, its presence in the Arctic region, the EU intervention must be "accepted" and seen as "legitimate"

* Mar Campins Eritja, Professor, Department of International Law and Economics, Universitat de Barcelona; Centre d'Estudis de Dret Ambiental de Tarragona (CEDAT).

** This paper is part of a larger research project funded by the Spanish Ministry of Economy and Competitiveness (Reference: DER2013-440og-P): "From sustainable development to environmental justice: Towards a conceptual template for global governance", led by Antoni Prigrau Sole, Universitat Rovira i Virgili.

1 NASA, Ice-Bridge Arctic 2015 <http://www.nasa.gov/mission_pages/icebridge/index.html\# .Vb-xELfTOf $4>$ accessed 1 September 2015 .

2 Government of Greenland, Greenland in Figures (2014) <www.stat.gl/publ/da/G F/2014/pdf/> accessed 1 September 2015 . 
by local players. Therefore, this Chapter will also discuss the recognition by the EU of the Greenlandic population's rights concerning participation in the context of offshore extractive operations. Although the issue has never been high on the EU political agenda, indigenous rights protection is one of the reasons why the EU has justified its interest in the Arctic. However, EU law has so far been scarcely affected by the evolution of international law regarding the rights of indigenous peoples. Finally, this Chapter will focus on how the current EU - Greenland relationship can be used to strengthen this dialogue. The privileged and unique position of Greenland may serve potentially to strengthen the role of the EU in the region, and ultimately, an enhanced cooperation has mutual benefit.

2

\section{The General Current Legal Framework for the Greenland and the EU Relationship}

Greenland and the Eu have a special relationship. Greenland is an autonomous territory of a Member State (Denmark) of the EU that has exercised its right of withdrawal from the EU. In spite of not being a part of the $\mathrm{EU}$, Greenland historically remains closely associated to the EU through an important partnership. Besides, as one of main EU Overseas Countries and Territories (остs), Greenland has a geostrategic location between Europe and America. At the same time, Greenland is also strategically important to ensure the EU's presence in the Arctic.

\subsection{Greenland's Self-governance Process}

In order to fully understand the role of Greenland in the Eu's Arctic strategy, it is necessary to refer briefly to the State-building process in which this territory has been immersed since the 1970s. Greenland has been and still is a territory dependent on Denmark. Political parties on the island were established in the 1970s, which have been pressing for a new institutional relationship with Denmark and strengthening aspirations towards independence. This is a process that began with the adoption of the Home Rule Act of $1978,{ }^{3}$ which was adopted as a result of Denmark's accession to the European Economic Community (EEC) in 1973. Through the Home Rule Act, a wide autonomy

3 Act No. 577 of 29 November 1978, The Greenland Home Rule Act, English translation available at <http://www.stm.dk/_p_12712.html > accessed 1 September 2015. 
regime for Greenland was established. Until the early 2000s, the position of the Greenlandic government under the leadership of Premier Jonathan Motzfeldt was to urge slow construction of a politically and economically viable State and prioritize the relations with the Nordic countries. It was not until the turn of the century that Greenland had to face the choice between building a new independent State through a process of expedition, an option at that time presented by the government of Premier Hans Enoksen (between 2002 and 2009); or first turn Greenland into an economically autonomous actor and deal with the political process of independence later, a more pragmatic approach which has been defended by the government of the Premier Kuupik Kleist since 2009. ${ }^{4}$

2009 marked a turning point in this process. On 25 November 2008, 75.5\% of Greenlanders voted in favour of a proposal for broad autonomy developed by the Greenlandic-Danish Self-Rule Commission. As a result of this decision Act $\mathrm{N}^{\circ} 473$ on Greenland Self-Government (AGSG) was passed by the Danish Parliament on 12th June 2009, ${ }^{5}$ which replaced the Home Rule Act of 1978 . The Act of 2009 allows the government of Greenland to assume legislative, executive and judicial powers, which Danish authorities had until then. By virtue of the Act, Denmark keeps its power regarding foreign affairs, defence and economic policy. However, the importance of being an "Arctic State" is clear to Denmark. For this reason, its Arctic strategy, which was presented in 2011, ${ }^{6}$ focuses on cooperation with the Faroe Islands and Greenland in a win-win approach to Arctic issues.

The preamble to the AGSG refers to "the people of Greenland" and acknowledges their capacity as "a people pursuant to international law with the right of self-determination." Consistent with this provision, the Act contains a specific regulation on the access of Greenland to independence. Its chapter eight

4 Alex Kjoer Sorensen, Denmark-Greenland in the Twentieth Century (Commission of Scientific Research in Greenland-Kristen Caning, Greenland, 2006); Damien Degeorges, The role of Greenland in the Arctic, (2012) 7 Laboratoire de l'IRSEM, 16 <http://www.defense.gouv.fr/ irsem/publications/laboratoire/laboratoire-de-l-irsem-2012/laboratoire-de-l-irsem-n-7-2012> accessed 1 September 2015.

5 Act no. 473 of 12 June 2009, Act on Greenland Self-Government, English translation available at <http://www.stm.dk/_a_2957.html > accessed 1 September 2015.

6 Ministry of Foreign Affairs of the Danish Government, Department of Foreign Affairs of the Government of Greenland, Ministry of Foreign Affairs of the Government of the Faores, Denmark, Greenland and the Faroe Islands: Kingdom of Denmark Strategy for the Arctic 2011-2020 (2011) <http://usa.um.dk/en/ /media/USA/Arctic_strategy.pdf> accessed 1 September 2015. 
establishes that if the people of Greenland adopt a decision in favour of independence by referendum, appropriate negotiations should be started between the Danish government and the Greenlandic government (Naalakkersuisut), so as to adopt an agreement that regulates Greenland's way out of Denmark's territory. This agreement, which must be submitted again to referendum, must have the consent of the Danish Parliament, as established in Section 19 of the Danish Constitution. ${ }^{7}$

\subsection{Current Relationship between Greenland and the $\mathrm{EU}$}

Denmark's accession to the EEC in 1973 was strongly opposed in Greenland. Although $70.8 \%$ of the Greenlandic population voted against the accession in the referendum of October $1972,{ }^{8}$ they could not prevent the incorporation of the territory into the EEC as a part of the Kingdom of Denmark. Again, in February 1982 Greenland's population expressed its position against its continuance in the EEC with a negative vote of $53.02 \%$. As a consequence, the Danish government presented a proposal to change the legal status of Greenland within the EEC, signing a new Treaty in 1984. Greenland formally withdrew from the EEC in $1985 .{ }^{9}$ Therefore, the Treaty of the European Union (TEU) and the Treaty on the Functioning of the European Union (TFEU) do not apply to Greenland. The island, as part of a EU Member State, has been associated to the EU as one of the остs, a status created to incorporate former French, Dutch and British colonies. Since then, the current legal framework for relations between the EU and Greenland consists of three main instruments: the Decision of Association ${ }^{10}$ together with the Joint Declaration on relations

7 Translation in English available online at $<$ http://www.servat.unibe.ch/icl/daooooo_ .html $>$ accessed 1 September 2015 .

8 On the whole process, see Alex Kjoer Sorensen, n. 4 above, 145 .

9 Treaty of 30 March 1984 amending with regard to Greenland, the Treaties establishing the European Communities, [1985] of L29. See also, Friedl Weiss, "Greenland's withdrawal from the European Communities" [1985] 1o European Law Review 173; and Frederik Harhoff, "Greenland's Withdrawal from the European Communities" [1983] 20 Common Market Law Review 13.

10 Council Decision 2014/137/EU, of 14 March 2014, on relations between the European Union on the one hand, and Greenland and the Kingdom of Denmark on the other, [2014] oJ $\mathrm{L}_{7} 6$. 
between the EU and Greenland; ${ }^{11}$ the Fisheries Agreements; ${ }^{12}$ and the Overseas Association Decision with the остs. ${ }^{13}$

Greenland has had constant cooperation with the EU since 2007, which has been consolidated by the Decision of the Council 2014/137/EU for the 2014-2020 period. The Council Decision 2014/137/EU has a twofold aim: first, the Decision pursues strengthening the cooperation with Greenland to face its major challenges - sustainable diversification of its economy in particular. Second, the EU's action aims to contribute to improving the capacity of Greenland's administration to formulate and implement national policies, particularly in areas of mutual interest.

According to Article 3 of the Council Decision 2014/137/EU, the main areas for cooperation for the 2014-2020 period are: a) education and training, tourism and culture; b) natural resources, including raw materials; c) energy; d) climate; e) the social sector, mobility of the workforce, social protection systems, food safety and food security issues; and f) research and innovation in areas such as energy, climate change, disaster resilience, natural resources, including raw materials and the sustainable use of living resources. The

11 At that time, Joint Declaration by the European Community, on the one hand, and the Home Rule Government of Greenland and the Government of Denmark, on the other, on partnership between the European Community and Greenland, [2006] oJ L208; and Joint Declaration by the European Union of 19 March 2015, on the one hand, and the Government of Greenland and the Government of Denmark, on the other, on relations between the European Union and Greenland, <https://ec.europa.eu/europeaid/sites/devco/files/ signed-joint-declaration-eu-greenland-denmark_en.pdf > accessed 2 February 2016.

12 At that time, Council regulation (EEC) 224/85 of 29 January 1985, on the conclusion of the Protocol on the conditions relating to fishing between the European Economic Community, on the one hand, and the Government of Denmark and the local Government of Greenland, on the other, [1985] OJ L29; Council Regulation (EC) 753/2007 of 28 June 2007, on the conclusion of the Fisheries Partnership Agreement between the European Union on the one hand, and the Government of Denmark and the Home Rule Government of Greenland, on the other hand [2007] oJ L172; and Council Decision 2015/2103 of 16 November 2015, on the signing, on behalf of the European Union, and the provisional application of the Protocol setting out the fishing opportunities and financial contribution provided for in the Fisheries Partnership Agreement between the European Community on the one hand and the Government of Denmark and the Home Rule Government of Greenland, on the other hand [2015] OJ L305.

13 At that time, Council Decision 80/1186/EEC of 16 December 1980, on the Association of Overseas Countries and Territories with the European Economic Community, [1980] oJ $\mathrm{L}_{3} 61$; and Council Decision 2013/755/EU on the association of the overseas countries and territories with the European Union [2013] oJ L344. 
amount of financial assistance from the EU is EUR 218 million for the 20142020 period. This amount is allocated almost entirely to the education sector. In turn, this financial contribution is executed by the Greenlandic administration through a Programming Document for the Sustainable Development of Greenland (PDSD), ${ }^{14}$ which defines the priorities for the 2014-2020 period (education, professional training and secondary schooling). The Association has been strengthened by the Joint Declarations on relations between the EU and Greenland and Denmark in 2006 and $2015 .{ }^{15}$ While it is a programme document and so is not legally binding, it confirms the EU's ties with Greenland and reiterates the geostrategic importance of Greenland to the EU.

The first fishery agreement between the EU and Greenland was carried out in 1985 following the withdrawal of this territory from the EEC..$^{16}$ In 2007 , the Council adopted Council Regulation (EC) No 753/2007 of 28 June 2007 on the conclusion of the Fisheries Partnership Agreement between the European Community and the Government of Denmark and the Home Rule Government of Greenland. ${ }^{17}$ In January 2013, Council Regulation (EU) No 927/2012 of 16 July $2012,{ }^{18}$ set out fishing opportunities in the Exclusive Economic Zone (EEZ) of Greenland and the EU financial contribution. It was followed by Council Decision 2014/48/EU on the conclusion of the Protocol setting out the fishing opportunities and financial contribution provided for in the Fisheries Partnership Agreement. ${ }^{19}$ With the current EU Decision 2015/2103/EU, ${ }^{20}$ a new Protocol applying to the fishing relations between the EU and Greenland for the period January 2016 to December 2020 was adopted and completes this EU regulation.

Finally and according to Annex II of the TFEU concerning OCTs, Greenland also benefits from the special regime described in Part IV of the TFEU and Protocol $\mathrm{n}^{\circ} 34$ applicable to остs. This regime is developed in the Overseas

14 Programming Document for the Sustainable Development of Greenland 2014-2020, annexed to Council Decision 2014/137/EU on relations between the European Union on the one hand and Greenland and the Kingdom of Denmark on the other, [2014] oJ L76. [2006] OJ L208 and Joint Declaration by the European Union, on the one hand, and the Government of Greenland and the Government of Denmark, on the other, on relations between the European Union and Greenland, 19 March $2015<$ https://ec.europa.eu/ europeaid/sites/devco/files/signed-joint-declaration-eu-greenland-denmark_en.pdf> accessed 2 February 2016.

16 [1985] OJ L29.

$17 \quad[2007]$ OJ L172.

18 [2012] OJ L293.

19 [2014] OJ L28.

$20 \quad$ [2015] OJ L305. 
Association Decision 2013/755/EU of 25 November 2013 on the association of the overseas countries and territories with the European Union, ${ }^{21}$ which replaces the former Decision of 2001. ${ }^{22}$ The main purpose of the Decision $2013 / 755 / \mathrm{EU}$ is to establish an association with the остs on the basis of "objectives, principles and values shared by the остs, the Member States to which they are linked and the Union". ${ }^{23}$ This specially means "the enhancement of the остs competitiveness, the strengthening of the остs' resilience, the reduction of their economic and environmental vulnerability and the promotion of cooperation between them and other partners" and respect for "the fundamental principles of liberty, democracy, human rights and fundamental freedoms, the rule of law, good governance and sustainable development". ${ }^{24}$

In Decision 2013/755/EU two specific situations are found with regard to Greenland, which has a different position comparing to the rest of octs. Firstly, Article 3 of Annex II of the Decision provides that all остs other than Greenland receive EUR 229.5 millions to carry out the objectives of the Decision. Greenland alone receives EUR 218 millions for the same period. Secondly, the Decision mentions specifically the importance of proper waste management in fragile island environments of the остs and refers to the application of Article 198 of the EURATOM Treaty regarding radioactive waste. Greenland again is an exception that the EURATOM Treaty does not apply to. ${ }^{25}$

\section{3}

The Recognition and Development of the Rights of the Greenland Population by the EU

The EU has expressed great interest in the huge potential of Arctic natural resources, especially hydrocarbons. The offshore exploration and exploitation of hydrocarbons involve several activities from seismic exploration to dismantling the infrastructure when the operation ceases. Depending on their dimensions and the technology used, offshore activities have considerable economic, social and environmental impact. ${ }^{26}$ In particular this is a very

\footnotetext{
$21 \quad$ [2013] OJ L344.

$22 \quad$ [2001] oJ L314 and [2001] oJ L324.

23 Para. 1, Article 3, Overseas Association Decision 2013/755/EU.

24 Para. 2, Article 3, Overseas Association Decision 2013/755/EU.

25 Para. 23, Preamble, Overseas Association Decision 2013/755/EU.

26 National Research Council of the National Academies, Responding to Oil Spills in the US Arctic Marine Environment (The National Academies Press, 2014). The Arctic Council has also addressed the issue through several instruments: See Ruling adopted within the
} 
sensitive issue for the indigenous communities inhabiting the Arctic region and therefore for Greenlandic population, of whom $85 \%$ are Inuit. Although it has positive impacts such as economic growth (i.e. employment opportunities, better health and education), its social and cultural impact on Arctic indigenous communities has been questioned (i.e. urbanization of the region, alteration of landscape and cultural, economic and traditional issues, reduction of hunting). ${ }^{27}$ Therefore it is necessary to clarify indigenous peoples' rights to participate in the decision-making processes relating to offshore exploration and exploitation.

\subsection{The Rights of Indigenous Peoples in General International Law}

Contemporary international law addresses the situation of indigenous peoples from a quadruple perspective: $\left.{ }^{28} \mathrm{i}\right)$ international treaties protecting human rights at the universal level (the Universal Declaration of Human Rights of 1948 and the International Covenants on Human Rights of 1966); ${ }^{29}$ ii) the establishment of specific UN bodies (Working Group on Indigenous Populations, UN

Arctic Council Agreement on Cooperation on Aeronautical and Maritime Search and Rescue in the Arctic, (2011) <https://www.ifrc.org/docs/idrl/N813EN.pdf>; and Agreement on Cooperation on Marine Oil Pollution, Preparedness and Response in the Arctic (2013) <http://www.arctic-council.org/eppr/agreement-on-cooperation-on-marine-oil-pollu tion-preparedness-and-response-in-the-arctic $>$ accessed 1 September 2015; See also the non mandatory Arctic Offshore Oil and Gas Guidelines, Arctic Council (PAME Working Group, 3rd edition, 2009) <http://www.pame.is/index.php/projects/offshore-oil-and-gas> accessed 1 September 2015 .

27 National Research Council of the National Academies, Cumulative environmental effects of oil and gas activities on Alaska's North Slope (The National Academy Press 2003) <http:// dels-old.nas.edu/dels/rpt_briefs/north_slope_final.pdf> accessed 1 September 2015 . See also, Rachel Lorna Johnstone, Offshore Oil and Gas development in the Arctic under International Law: Risk and Responsibility, (Brill, 2015) 59.

28 See Antoni Pigrau Solé, "Los pueblos indígenas ante el Derecho Internacional", in Antoni Pigrau Solé, (Ed.), Pueblos indígenas, diversidad cultural y justicia ambiental. Un estudio de las nuevas constituciones de Bolivia y Ecuador (Tirant lo Blanch 2013) 61. See also, Siegfried Wiessner, "La Déclaration des Nations Unies sur les droits des peuples autochtones" in United Nations Audiovisual Library of International Law (UN Bureau des Affairs Juridiques 2009) $2<$ http://legal.un.org/avl/pdf/ha/ga_61-295/ga_61-295_f.pdf> accessed 1 September 2015; and Patrick Thornberry, The Rights of Minorities and Indigenous Peoples, in Forum Deusto, Los Derechos Humanos en un mundo dividido, (Deusto University 1999) 163, 165185 and $168-169$.

29 Universal Declaration of Human Rights of 10 December 1948, UNGA Resolution 217 A (III); International Covenant on Civil and Political Rights of 16 December 1966, 999 U.N.T.S. 171, and International Covenant on Economic, Social and Cultural Rights of 16 December 1966, 993 U.N.T.S. 3; Resolution 2200 A (XXI) AGNU, 16 December 1966. 
Permanent Forum on Indigenous Issues, Special Rapporteur on the Rights of Indigenous Peoples, and the Expert Mechanism on the Rights of Indigenous Peoples, replaced in 2007 by the Working Group on Indigenous Populations); iii) the consideration of indigenous people in the framework of the International Labour Organisation (ILO) in particular through the Indigenous and Tribal Peoples Convention $\mathrm{N}^{\circ} 169$ of $1989 ;{ }^{30}$ and iv) the adoption of the UN Declaration on the Rights of Indigenous Peoples in 2007. ${ }^{31}$ However, the case for the Greenlandic population is quite unique in that, if Greenland becomes fully independent, it will be the only Arctic country with a majority indigenous population.

At the international level, the rights of the Arctic's indigenous peoples are fundamentally contained in two texts. ${ }^{32}$ ILO Convention $\mathrm{N}^{\circ} 169$ of 1989 on the Indigenous and Tribal Peoples has already had an impact on States' public policies. ILO Convention $\mathrm{N}^{\mathrm{o}} 169$ particularly recognizes the rights of ownership over the lands indigenous peoples traditionally occupy (Article 14); the right to participate in the use, management and conservation of natural resources on their land (Article 15); and the right not to be moved from the lands they occupy (Art. 16). The UN Declaration on the Rights of Indigenous Peoples (UNDRIP), adopted by the General Assembly in 2007 recognizes the right not to be forcibly moved from their lands or territories (Article 10); the right to the lands, territories and resources traditionally owned or otherwise used or acquired (Article 26); the right to the preservation and protection of their environment and the productive capacity of their lands or territories and resources (Article 29) and the right to use their own means of subsistence and development, and to engage freely in all their business activities, traditional and other (Article 20).

30 Convention $\mathrm{N}^{\mathrm{o}} 169$ concerning Indigenous and Tribal Peoples in Independent Countries of 27 June 1989 <http://www.ilo.org/dyn/normlex/en/f?p=NORMLEXPUB:1210o:o::NO :12100:P1210o_INSTRUMENT_ID:312314:NO> accessed 1 September 2015. So far only 22 States have ratified it (amongst them only Denmark and Norway in the Arctic area); ILO <http://www.ilo.org/dyn/normlex/en/ f?p=NORMLEXPUB:11300:0::NO:1130o:P11300_ INSTRUMENT_ID:312314:NO > accessed 1 September 2015.

31 Resolution adopted by the UN General Assembly 61/295 United Nations Declaration on the Rights of Indigenous Peoples (2007) <http://www.un.org/esa/socdev/unpfii/ documents/DRIPS_en.pdf $>$ accessed 1 September 2015 .

$3^{2}$ For a deeper analysis, See Antoni Pigrau Solé, Mar Campins Eritja, Xavier Fernández Pons, "Union européenne et droits des peuples autochtones de l'Arctique: Terres, ressources et consentement", in Nathalie Herve-Fournereau (Coord.), Peuples autochtones et intégrations régionales, Réseau Thématique Pluridisciplinaire BIODISCEE, CNRS INEE (Université de Rennes, forthcoming 2017), 2 ff. 
The right to be consulted appears in both texts. Article 6 of the ILO Convention $\mathrm{N}^{\mathrm{o}} 16 \mathrm{~g}$ states that

governments shall: (a) consult the peoples concerned, through appropriate procedures and in particular through their representative institutions, whenever consideration is being given to legislative or administrative measures which may affect them directly; (b) establish means by which these peoples can freely participate, to at least the same extent as other sectors of the population, at all levels of decision-making in elective institutions and administrative and other bodies responsible for policies and programmes which concern them.

In a more specific way, in other hypothetical cases, consultation is the obligatory procedure when any restriction over the rights of land and resources occurs. When the State is the owner of mineral or hydrocarbon resources including sub-surface resources, the governments "shall establish or maintain procedures through which they shall consult these peoples, (...) before undertaking or permitting any programmes for the exploration or exploitation of such resources pertaining to their lands." (Article 15); and "whenever consideration is being given to their capacity to alienate their lands or otherwise transmit their rights outside their own community." (Article 17)

The UNDRIP also refers to the obligation to take certain measures "in consultation with the indigenous peoples" in various articles (Article 15.2, 17.2 36.2 and 38). But in certain cases, the Declaration refers explicitly to the fact that the consultation should be carried out to obtain the free, prior and informed consent of the indigenous peoples. That is the case in Article 19, concerning the adoption and implementation of legislative or administrative measures, and in Article 32, regarding the right of indigenous peoples to determine and develop priorities and strategies for the development or use of their land and other resources. The mention of obtaining the consent and the use of such adjectives as 'prior', 'free' and 'informed' show the way consultation should be done carried out, but that does not imply that there is an absolute right to veto from the indigenous community over the adoption of the measure. However, these considerations should apply to all regulations that stipulate consultation and not only those which explicitly mention free, prior and informed consent. ${ }^{33}$ Moreover, the consultation should be a public process under the responsibility

33 Resolution adopted by the General Assembly on 22 September 2014, A/REs/69/2, Outcome Document of World Conference on Indigenous Peoples (2014) <http://wcip2014.org/wp -content/uploads/2013/03/N1446828.pdf > accessed 1 September 2015. 
of the State involved and cannot be delegated to other actors such as private companies. ${ }^{34}$

Finally, concerning the right of participation, the ILO Convention $\mathrm{N}^{\circ} 169$ provides the right of indigenous peoples to participate in the formulation, implementation and evaluation of national and regional development plans which may affect them directly (Article 7) and in the use, management and conservation of their natural resources (Article 15). The UNDRIP also refers in a general way to the right of indigenous peoples to participate, if they so choose, in the political, economic, social, and cultural life of the State (Article 5) and "in decision-making in matters which would affect their rights, through representatives chosen by themselves in accordance with their own procedures, as well as to maintain and develop their own indigenous decision-making institutions" (Art. 18). ${ }^{35}$ Aware of this obligation, the indigenous communities of the Arctic have demanded a greater involvement in decision-making processes that may affect them, ${ }^{36}$ in so far as the

34 Indigenous and Tribal Peoples' Rights over their Ancestral Lands and Natural Resources. Norms and Jurisprudence of the Inter-American Human Rights System, OEA/Ser.L/V/ II. Doc. 56/o9 (2009), par. 291 <http://www.oas.org/en/iachr/indigenous/docs/pdf/ ancestrallands.pdf $>$ accessed 1 September 2015.

35 See also Articles 23, 27 and 41.

36 The Declaration of the Inuit Circumpolar Conference on sovereignty in the Arctic of April 2009 considers that the right "to freely determine our political status, freely pursue our economic, social, cultural and linguistic development, and freely dispose of our natural wealth and resources" is fundamental as it refers to the rights recognised by the Declaration of 2007, which specifically mentions "the right to own, use, develop and control our lands, territories and resources and the right to ensure that no project affecting our lands, territories or resources"; Inuit Circumpolar Council, A Circumpolar Inuit Declaration on Sovereignty in the Arctic (2009) <http://www.inuitcircumpolar.com/sovereignty-in-the -arctic.html> accessed 1 September 2015. In May 2011 a new Declaration on Resource Development Principles in Nunaat identifies "many principles that are relevant to the governance and carrying out of resource development in Inuit Nunaat, including the importance of the rule of law and recognition of the rights of Inuit as an Arctic indigenous people under both international and domestic law"; Inuit Circumpolar Council, Arctic Circumpolar Inuit Declaration on Resource Development Principles in Inuit Nunaat (2011) $<$ http://www.inuitcircumpolar.com/resource-development-principles-in-inuit-nunaat .html> accessed 1 September 2015. The Athabaskan Council also pointed out that: "It is important, however, that as European states and the institutions of the EU develop a policy or dimension for the Arctic that "common concern" is not confused with "common property." Nordic Council of Ministers, Arctic Conference: Common Concern for the Arctic, Europe and the Arctic: A View From the Arctic Athabaskan Council, Ilulissat, (2008) 6 <https://www.norden.org/no/nordisk-ministerraad/samarbeidsministrene-mr-sam/arktis/ common-concern-for-the-arctic/den-europeiske-union-og-arktis/europe-and-the-arctic -a-view-from-the-arctic-athabaskan-council-aac-pdf> accessed i September 2015. 
respect for their interests can only be ensured through more participatory processes. $^{37}$

\subsection{The Rights of Arctic Indigenous Peoples in the EU Law}

Strictly speaking, although three of the EU Arctic Member States have indigenous peoples in their territories (Saami in Finland and Sweden, and Inuit in Denmark-Greenland), it cannot be said that the EU has a genuine policy for the protection of these communities. In fact, the Saami are the only indigenous peoples within the EU who are recognized as such and to whom participation in issues affecting their status as indigenous peoples is ensured. It is not a surprise, then, that the EU founding Treaties have never made any mention of indigenous peoples. The only exception is a very short reference in the Act of Accession of Austria, Sweden and Finland of 4 May 1994. Protocol 3 refers to the Saami people. ${ }^{38}$ Its two articles recognize the dependence of the Saami regarding certain traditional activities and restrict the European Community (EC) competence on the internal market in terms of reindeer breeding, in which the Saami are attributed exclusive rights. However, the EU has been developing several initiatives for the protection of the indigenous peoples in two complementary dimensions: a) international cooperation and human rights protection, and b) the strategy for the Arctic.

\subsubsection{International Cooperation and Human Rights Issues}

The EU has incorporated cooperation and assistance to indigenous peoples as part of a wider cooperation and development programmes. The incorporation has been effected from a welfare perspective, in which it is assumed that these communities have to face economic, social and political marginalization and constant violation of human rights originating from and aggravated by the underdevelopment of the areas where they are located. ${ }^{39}$ This is indeed, the approach that has traditionally supported the EU action in this area. In this

37 Anika E. Nilsson (Dir.), Arctic Resilence Interim Report 2013 (Stockholm Environment Institute-Stockholm Resilience Centre, 2013), 23 <http://www.sei-international.org/ mediamanager/documents/Publications/ArcticResilienceInterimReport2013-HighRes .pdf $>$ accessed 1 September 2015 .

38 Protocol No 3 on the Sami People, [1994] OJ C241, 352.

39 As an example, the 2002 Council's position refers to the possibility of integrating the groups of indigenous peoples into political dialogue with the third country partners, as an integral part of the clauses of respect for human rights of the cooperation and association agreements; See Council Meeting General Affairs and External Relations of 18 November 2002, 2463rd, General Affairs, 14183/02 <http://www.consilium.europa.eu/ ueDocs/cms_Data/docs/pressData/en/gena/73248.pdf> accessed 1 September 2015. 
regard, the position adopted by the Council, the European Parliament and the Commission in December $2005^{40}$ in which the primary objective was poverty eradication in the framework of sustainable development stands out. To do this, it establishes the use of social dialogue as the principal means to defend the rights of indigenous peoples and emphasizes the role of "full participation and free, prior and informed consent" of the indigenous communities in regards to those issues affecting them as the main mechanism to safeguard their rights. A key element is the participation of these communities in all stages of the adoption and implementation of projects and programmes that affect their livelihoods. The Commission has been establishing practical methods to guarantee the consultations, especially emphasizing the creation of contact points within the key services used to liaise with these groups, ${ }^{41}$ as well as the creation of an informal network comprising organisations of indigenous peoples. ${ }^{42}$

However, in contrast to what happens within the Arctic Council, which has significantly strengthened the participation of indigenous peoples in decision-making processes, ${ }^{43}$ the $\mathrm{EU}$ approach regarding these communities is much more limited. Despite the stance taken by the Commission and the European Parliament in this regard, the EU practice does not seem to be particularly sensitive to the demands of the indigenous peoples of the Arctic region. On the one hand, the EU approach is limited to the rights of minorities, the only dimension that is included in the TEU (Article 2) and in the

40 Statement of the Council and the representatives of the governments of the Member States meeting within the Council, the European Parliament and the Commission on the development policy of the European Union entitled “The European Consensus", [2006] oJ C46, par. 97, 101 and 103 .

41 The European Commission's / RELEX's Programming Guide for Strategic PapersProgramming Cycle. Democracy and Human Rights [2008] <http://ec.europa.eu/ europeaid/sites/devco/files/programming-guide-strategy-papers-democracy-humanrights-200812_en_2.pdf > accessed 1 September 2015.

42 Report from the Commission to the Council of 11 June 2002. Review of progress of working with indigenous peoples, сом (2002) $291 \mathrm{final}<\mathrm{http}$ //eur-lex.europa.eu/legal-content/ EN/TXT/?uri=URISERV:r120o6 $>$ accessed 1 September 2015. There are contact points in the RELEx (Human Rights and Democracy Network), Development (Civil Society), Environment ( $\mathrm{CBD}$ and Indigenous People Office) and the EuropeAid Co-operation Office (Human Rights and Democracy Network). The contact points cooperate closely with the geographical departments of the different services, the Commission delegations, and the representations of the Member States.

43 Timo Koivurova and Leena Heinamaki, "The participation of indigenous peoples in international norm-making in the Arctic" (2006) 42 (2) Polar Record 101. 
Charter of Fundamental Rights of the EU (Preamble and Article 21). ${ }^{44}$ That said, it has to be remembered that the EU has no mechanism to apply these principles beyond the territory of its Member States (Article 6, TEU). On the other hand, from the perspective of the international recognition of the specific rights of indigenous peoples, it is worth noting the scant participation of the EU in different international instruments. The EU has an almost insignificant presence in the ILO Convention $N^{\circ} 169$, which has only been ratified by three Member States (Denmark in 1996, The Netherlands in 1998 and Spain in 2007). Furthermore, although the EU has repeatedly expressed its support for the UNDRIP of $2007,{ }^{45}$ and allegedly uses this instrument as a basis for the periodic review of its human rights policy, ${ }^{46}$ it should not be forgotten that in the case concerning the trade ban in seal products, the Court of Justice of the European Union (CJEU) dismissed the mandatory character of the UNDRIP noting its non-binding nature. Regarding this instrument, it considered that

a measure adopted by virtue of those powers must be interpreted, and its scope limited, in the light of the relevant rules of international law (...). The document relied on by the applicants is a declaration and thus does not have the binding force of a treaty. It cannot be considered that that declaration can grant the Inuit autonomous and additional rights over and above those provided for by Union law. 47

It is noteworthy that the CJEU did not even consider any interaction between the UNDRIP and other sources of international law, for example, the ILO Convention $\mathrm{N}^{\circ} 169$, the legal relevance of which was totally ignored. The CJEU therefore confined the rights claimed by the plaintiffs to the categories and

$44[2010]$ oJ C83.

45 European Union Delegation to the United Nations, 20 October 2014, New York—European Union Statement delivered by H.E. Ioannis Vrailas, Deputy Head of the European Union to the United Nations, United Nations General Assembly Third Committee on Item 65 a \& b: Rights of Indigenous People <http://eu-un.europa.eu/articles/en/article_15604_ en.htm $>$ accessed 1 September 2015 .

46 Declaration by Catherine Ashton, High Representative of the European Union for Foreign Affairs and Security Policy and Commission Vice-President on behalf of the European Union on the occasion of the International Day of the World's Indigenous Peoples, 9 August 2013; 9 August 2014, Brussels-Statement by the Spokesperson on the occasion of the International Day of the World's Indigenous Peoples <http://eu-un.europa.eu/ articles/es/article_12500_es.htm> accessed 1 September 2015 .

47 Case T-526/10 Inuit Tapiriit Kanatami and Others $v$ European Commission [2013], Digital Reports (Court reports-general) ECLI identifier: ECLI:EU:C:2013:625, par. 112. 
specific parameters of the EU Charter of Fundamental Rights. Moreover, the CJEU decided that, "the guarantees accorded by the rights to property cannot be extended to protect mere commercial interests or opportunities, the uncertainties of which are part of the very essence of economic activity". 48 It also denied the indigenous peoples' right to be heard, since the TEU did not establish any mandatory duty for consultation, and noted that the Commission had met several times with representatives of the indigenous peoples during the elaboration of the regulations. ${ }^{49}$

\subsubsection{The EU's Arctic Strategy and Indigenous Peoples}

The interest of the $\mathrm{EU}$ for the Arctic region was initially very one-sided, and did not appear until the end of the 1990s, as part of the Finnish initiative that gave finally birth to the Northern Dimension. ${ }^{50}$ Within it, an "Arctic window" highlighted the need to involve Arctic indigenous peoples in the decision making process. In practice, it was not a big change, since the political interest that the region aroused then remained limited. However, it at least showed the recognition by the EU of the singularity of the Arctic with its special human, environmental and socio-economic conditions. Since then, the Eu has also developed a specific strategy for the Arctic, set out in three Commission's Communications (2008, 2012 and 2016).${ }^{51}$ However, the approach of the Commission concerning indigenous peoples appears to be fragmentary and limited.

$48 \quad$ Ibid. par. 109. For a deeper comment, See Antoni Pigrau Solé, Mar Campins Eritja, Xavier Fernández Pons, n. 32 above, 21.

49 Case T-526/10 Inuit Tapiriit Kanatami and Others $v$ European Commission [2013], Digital Reports (Court reports-general) ECLI identifier: ECLI:EU:C:2013:625, par. 113.

50 Political Declaration on the Northern Dimension Policy of 24 November 2006 and Northern Dimension Policy Framework Document of 24 November $2006<$ http://ndep .org/wp-content/uploads/Political-Declaration-on-the-Northern-Dimension-Policy.pdf> and <http://ndep.org/wp-content/uploads/Northern-Dimension-Policy-Framework.pdf> accessed 1 September 2015. The Northern Dimension represented a new approach to external borders of the $\mathrm{EU}$ and its adjacent areas and seeks to promote security and stability in the region, while taking advantage of the potential of the region in terms of both natural resources and economic dynamism.

51 European Commission Communication of 20 November 2008 on the European Union and the Arctic Region, сом (2008) 763.; Joint Communication of the European Commission and High Representative of the European Union for Foreign Affairs and Security Policy of 26 June 2012 on Developing a European Union Policy towards the Arctic Region: Progress since 2008 and Next Steps, JOIN (2012) 19; Joint Communication of the European Commission and High Representative of the European Union for Foreign Affairs and Security Policy of 27 April 2016 on An Integrated European Union Policy for the Arctic, JOIN (2016) 21 final. 
In its 2008 Communication, the Commission identifies two political goals that are essential for this purpose: $i$ ) the protection and preservation of the Arctic in accordance with its population (avoiding and mitigating the negative impact of climate change and supporting adaptation to inevitable changes); and ii) the promotion of sustainable exploitation of Arctic resources. To achieve the first goal, the Commission included the requirement for the participation of Arctic indigenous peoples by establishing a regular dialogue, although it did not set up a specific institutional framework. In this context, the financial measures taken by the EU in several areas of this region have been of particular importance, especially the ones related to the European Neighbourhood Policy. ${ }^{52}$ The second of these goals has a particular impact on the right of indigenous peoples to exploit their land and resources, since climate change impacts clearly on four areas essential for sustainable development of the Arctic and its populations, as mentioned in the 2008 Communication: hydrocarbons, fishing, transport and tourism.

Over the course of four years there were no major advances in the realisation of these goals. In the 2012 Communication, the Commission dilutes the significance of indigenous peoples' involvement in a more general commitment to dialogue with Arctic countries, indigenous peoples and other interested stakeholders. In addition, direct references to action for the protection of indigenous peoples are scanty. The Communication merely mentions, among a long list of measures carried out in each dimension since 2008 (within three big areas: knowledge, responsibility, commitment), the actions of financing sustainable development of local communities, conducting regular dialogues and creating platforms to ensure that representatives from indigenous communities are informed and consulted on EU policies. ${ }^{53}$ Even with this limitation, the Commission's Communication highlights the role of the EU-Greenland relationships as being to promote "an enhanced dialogue on Arctic issues that would not only allow the EU to gain additional understanding of remote Arctic

$5^{2}$ European Union, European Arctic Initiatives Compendium. Preparatory Action, Strategic Environmental Impact Assessment of development of the Arctic (Arctic Centre, University of Lapland 2014), <https://lauda.ulapland.fi/bitstream/handle/10024/61853/ European_arctic_initiatives_compendium_pdfA.pdf?sequence $=2>$ accessed 1 September 2015. In particular, Northern Periphery and Arctic Programme Secretariat, The Northern Periphery and Arctic Programme 2014-2020 (2014, updated 2016) <http://www.interregnpa.eu/fileadmin/Programme_Documents/Approved_Cooperation_Programme_ Jan2016.pdf $>$ accessed 1 September 2015 .

53 JOIN (2012) 19, p. 12. This materialised between 2008-2012 in several «Arctic Dialogues» supported by the Commission, the last one took place in October $2014<\mathrm{https} / /$ webgate .ec.europa.eu/maritimeforum/en/node/3655> accessed 1 September 2015. 
societies, and also allow for the sharing of valuable know-how on issues of mutual concern". ${ }^{4}$

The Council welcomed these initiatives, ${ }^{55}$ but also required the Commission and the High Representative "to present proposals for the further development of an integrated and coherent Arctic Policy by December 2015". ${ }^{56}$ Among its suggestions, it highlighted in particular the Council support to "strengthening the partnership between the European Union on the one hand, and Greenland and the Kingdom of Denmark on the other which aims at promoting the sustainable development of Greenland and the diversification of the economy" in a way that "also encourages an enhanced dialogue and cooperation on global and Arctic issues". 57 To this end, the 2016 Communication focuses on three main areas: climate change and the environment, sustainable economic development and international cooperation. In particular, the Communication wish to enhance the cooperation with indigenous peoples in order to ensure respect for their rights in the development of the Arctic policy and in the promotion of sustainable economic activities. Despite this focus on sustainable economic activities, the EU engagement is still too weak, it does not take into account the realization of specific actions and relies primarily on the annual dialogue with indigenous representatives organized by the Commission.

\section{$4 \quad$ The Legal Framework for Offshore Oil Extraction and the Participation of the Greenlandic Population in the Decision Making Process}

The protection of the rights of the indigenous peoples in relation to the exploitation of hydrocarbons is mostly addressed by the internal legal system of each Arctic State. Thus we need to examine Greenlandic law and in doing so we will check the issues raised against the EU specific regulations.

54 Ibid.p. 11.

55 Council Conclusions of 8 December 2009, on Arctic issues <http://ec.europa.eu/mari timeaffairs/policy/sea_basins/arctic_ocean/documents/arctic_council_conclusions_09_ en.pdf > accessed 1 September 2015; Council Conclusions of 12 May 2014, on developing a European Union Policy towards the Arctic Region <http://www.consilium.europa.eu/ uedocs/cms_data/docs/pressdata/EN/foraff/142554.pdf > accessed 1 September 2015.

56 Ibid, par. 15 .

57 Ibid, par. 13 . 


\section{1 The Relevance of Greenlandic Offshore Hydrocarbons Resources}

From a geological point of view, Greenland is one of the most interesting countries in the world. Its mineral and other natural resources are particularly important. ${ }^{58}$ In 2008 the Us Geological Survey carried out an evaluation of existing resources in the Arctic Circle and estimated that three main basins around Greenland could hold around 50,000 million barrels of oil and gas. In offshore areas of Northeast Greenland there would be estimated 31,00o million barrels of oil, while in the seabed between Greenland and Canada there would be another estimated 17,000 million. ${ }^{59}$

For years, Greenland has been struggling to consolidate an economically viable as well as sustainable hydrocarbon industry. Its future development, however, faces double challenges: on the one hand, the exploitation of these hydrocarbons is essential for Greenland's economic development. According to the vision of those in favour of political independence of Greenland from Denmark, the exploitation of those resources as well as fishing and navigation through Arctic waters are the basis for the construction of Greenland as a future sovereign State. ${ }^{60}$ On the other hand, from the environmental point of view, the management of these resources raises huge challenges in reconcil-

$5^{8}$ See Kenneth J. Bird, Ronald R. Charpentier, Donald L. Gautier et alt, Circum-Arctic Resource Appraisal: Estimates of Undiscovered Oil and Gas North of the Arctic Circle (U.s. Geological Survey 2008) <http://pubs.usgs.gov/fs/2008/3049/fs2008-3049.pdf> accessed 1 September 2015 .

59 As other Arctic States, this has led Denmark, jointly with Greenland, to submit three claims with regards to the extension of its Continental Shelf beyond 200 nautical miles. The first one (June 2012) affects the Continental Shelf south of Greenland, an area divided between the South-Western part of the Labrador Sea and Eastern part of the Irminger Sea. The second claim (November 2013) relates to the Continental Shelf off the Northeast of Greenland, affecting the area between Greenland and Svalbard. The third claim (December 2015) relates to the Northern Continental Shelf of Greenland. See Commission on the Limits of the Continental Shelf (CLCS) Outer limits of the continental shelf beyond 200 nautical miles from the baselines: Submissions to the Commission by the Kingdom of Denmark, <http://www.un.org/depts/los/clcs_new/submissions_files/ submission_dnk_61_2012.htm> accessed 27 October 2015; <http://www.un.org/depts/los/ clcs_new/submissions_files/submission_dnk_68_2013.htm> accessed 17 October 2015; and <http://www.un.org/depts/los/clcs_new/submissions_files/dnk76_14/dnk4_clcs76_2014_ en_fr.pdf $>$ accessed 10 September 2016.

6o Vestergaard Pedersen, "Regulation of Climate Matters in Greenland" [2012] 1 Carbon \& Climate Law Review 47. See also Marc Auchet, "'Greenland at the crossroads. What strategy for the Arctic?' [2011] 66 International Journal 957; Coco C.A. Smits, Jan P.M. van Tatenhove, Judith van Leeuwen, "Authority in Arctic governance: Changing spheres of authority in Greenlandic offshore oil and gas developments" [2014] 14 International Environmental Agreements 329 . 
ing economic growth based on hydrocarbons extraction, which is managed by limited human resources, with the conservation of the Arctic's highly sensitive environment.

Offshore oil drilling in the Arctic began in the mid-seventies. Since then, at least 61 large oil and gas fields have been located within the Arctic Circle. Norway and Russia are the main oil and gas exporters from the region; further west, Iceland and Greenland are also actively working on oil and gas exploration in their areas of jurisdiction. ${ }^{61}$ However, technical difficulties of carrying out offshore extraction of hydrocarbons in the region are obvious. The cost of prospecting and exploiting these resources in such a remote place and under such tough weather conditions affect the viability of exploitation. Navigation through Arctic waters, construction of artificial platforms, access to platforms through ice, and connecting sub-marine wells to onshore facilities are some of the difficulties. ${ }^{62}$ In addition, beyond geopolitical factors, the price of crude oil fell on the international market following the 2008 financial crisis, which provides less incentive for offshore oil drilling in the Arctic. This explains why, since 2014 some major companies have announced their intention to stop prioritizing their operations in Greenland, despite the willingness of the Greenlandic government "(...) to promote prosperity and welfare by creating new income and employment opportunities in the area of mineral resources activities" and its optimism about opening new wells between 2014 and 2018. ${ }^{63}$ For example, the British petrochemical company

$61 \quad$ Philip Budzik, Arctic Oil and Natural Gas Potential (U.s. Department of Energy, Energy Information Administration, 2009) <http://www.eia.gov/oiaf/analysispaper/arctic/pdf/ arctic_oil.pdf > accessed 1 September 2015 .

62 These difficulties meant that major projects in the region began to develop quite late. The KANUMAS project (Kalaallit Nunaat Marine Seismic) was not up and running until 1989, with the granting of prospecting licenses by the Danish Government to a consortium of companies (ExxonMobil, Statoil, BP, Japan National Oil Company, Texaco, Shell y Nunaoil) to investigate the oil potential in the Northwest and Northeast of Greenland. See Graça Ermida, "Strategic decisions of international oil companies: Arctic versus other regions" [2014] 2 Energy Strategy Reviews 265; Kevin Casey, Greenland's New Frontier: Oil and Gas Licences Issued, Though Development Likely Years Off (The Arctic Institute, 2014) <http://www.thearcticinstitute.org/2014/o1/greenlands-new-frontier-oil-and-gas.html> accessed 1 September 2015; Joanna Kay and Stine Thorup, "Oil and Gas in GreenlandStill on Ice?" (Notes From The Field - An English Law Perspective On The Oil \& Gas Market, November 2014) <https://www.andrewskurth.com/pressroom-publications-1165.html> accessed 1 September 2015 .

63 Government of Greenland, Greenland's Oil and Mineral Strategy 2014-2018, FM (2014) 133 $<$ http://naalakkersuisut.gl/ /media/Nanoq/Files/Publications/Raastof/ENG/Greenland \%20oil\%2oand\%2omineral\%2ostrategy\%202014-2018_ENG.pdf> accessed 1 September 2015 . 
Cairn Energy, which is the only company that has been continuously drilling in coastal areas of Greenland, has not yet achieved commercial use of these resources. This resulted in other oil companies, including Norwegian Statoil, French GDF Suez and Danish Dong Energy, giving up their exploration licenses. Currently, companies hold only 15 licenses to explore Greenlandic waters, ${ }^{64}$ but none of them seems to be actively drilling. However, that does not mean the hydrocarbon industry has given up exploiting the hydrocarbon resources in the region. In fact, the Greenlandic government has tried to maintain current levels of exploration activity in the hope that it will find other commercially viable wells. The Greenlandic government announced the launching of the first field with a reserve of about 500 million barrels of oil in 2020 and a second one in 2025 with a reserve of about 2,000 million barrels. In order to facilitate the exploration operations the government committed to grant new licenses between 2014 and 2018 in five new areas: Jameson Land (2014, onshore, East Greenland), South-West Greenland (2014, offshore), Disko-Nuussuaq (2016, offshore, West Greenland), Baffin Bay (2016/2017, Northwest Greenland), and Davis Straight (2018, West Greenland). ${ }^{65}$

\subsection{Greenland's Domestic Legal Framework}

Six months after the adoption of the Act $\mathrm{N}^{\circ} 473$ on Greenland Self-Government (AGSG), the Greenlandic Parliament approved the Mineral Resources Act (MRA). ${ }^{66}$ The AGSG and the MRA are intimately related and should be read in light of the internal political context, which considers economic benefits from

64 Mineral License and Safety Authority, List of Mineral and Petroleum Licences in Greenland, Government of Greenland [2015] <https://www.govmin.gl/images/stories/minerals/ list_of_licences/list_of_licences.pdf $>14-17$, accessed 1 September 2015. Exploration and exploitation licenses for hydrocarbons have been granted since 2002 (usually in joint ventures) to: Capricorn Greenland Exploration A/S (CAIRN: Edinburgh); NUNAOIL A/S (Greenland); Husky Oil Operations (Canada); PA Resources Aв (Sweden); Conoco Philips Global NVE Greenland Ltd (Norway); Shell Greenland (Anglo Dutch); Maersk Oil Kalaallit Nunaat A/S (Greenland); Tullow Greenland Exploration Ltd (UK); ENI Denmark BV (Denmark); вP Exploration Operating Company Ltd (UK); DONG E\&P Grönland A/S (Denmark); Statoil Greenland A/S (Norway); Chevron East Greenland Exploration A/S (USA), Greenland Petroleum Exploration Co. Ltd.

65 Government of Greenland, Greenland's Oil and Mineral Strategy 2014-2018, 8 February 2014, FM 2014/133, <http://naalakkersuisut.gl/ /media/Nanoq/Files/Publications/Raastof/ENG/ GOMS\%202014\%202018\%20Appendices\%2oENG.pdf> accessed 1 September 2015.

66 Act No. 7 of 7 December 2009 on Mineral Resources and Mineral Resource Activities, unofficial translation <https://www.govmin.gl/images/stories/faelles/mineral_resources_ act_unofficial_translation.pdf $>$ accessed 1 September 2015 . 
the exploitation of mineral and hydrocarbon resources to be inseparable from Greenland's aspirations for greater political independence.

As mentioned above, the AGSG does not use the term indigenous peoples or Inuit to refer to the Greenlandic population, nor does it consider that being from Greenland implies belonging to a particular ethnic group. As such, the Greenlandic legislation does not give special acknowledgment to Greenlanders as "indigenous peoples". Similarly, the MRA does not specifically refer to the subsistence or hunting activities of Greenland's population in its description of the characteristics of indigenous peoples, but talks about the protection of cultural values and the protection of animal and plant environment, and calls for a "rightful utilization of the soil, the sea, the subsoil or natural resources." Part 13 of the MRA relates specifically to environmental protection (Article $5^{1}$ to 54), climate protection (Article 55 to $5^{8}$ ) and to nature conservation (Article 59 to 62), in order "to help to protect the environment so that society can develop on a sustainable basis respecting human conditions of life and respecting preservation of animal and plant life."

Since the MRA came into force in January 2010, the government of Greenland has acquired the "right of use of and the right to exploit mineral resources in the subsoil in Greenland" (Article 2(1)). Since then, the Greenlandic authorities have assumed full powers over mineral resources in the subsoil. In so doing, the system of joint management between Greenland and Denmark and Denmark's power of veto, which had been in force since 1979, has come to an end. It is the government of Greenland which now grants drilling and exploitation licenses directly $^{67}$ and it is entitled to all the revenue derived from mining and hydrocarbon exploitation. ${ }^{68}$

The MRA seeks sustainable exploitation of mineral resources and hydrocarbons and proper use of the subsoil. Furthermore, it is intended to ensure that these activities are carried out in accordance with the requirements relating to health, safety, the environment, resource use and social sustainability, as well as in accordance with international best practice recognised in similar

67 The summary of licenses granted until 2013 in Government of Greenland, Greenland's oil and mineral strategy 2014-2018 (appendices), n. 65 above, 8-18, <http://naalakker suisut.gl/ /media/Nanoq/Files/Publications/Raastof/ENG/GOMS\%202014\%202018\%20 Appendices\%2oENG.pdf $>$ accessed 1 September 2015.

MRA Explanatory Notes, part 1.2.3, p.10, "The revenue definition", cited on Lisa Campion, Catherine Peterson and Zhen Zhang, "Greenland", in Vermont Law School Institute for Energy and the Environment, The Arctic Offshore Oil and Gas Guidelines in Greenland and The Russian Federation (Arctic Offshore Oil and Gas Guidelines White Paper No. 5, 2011) 1, note 9, p. 12 <http://www-assets.vermontlaw.edu/Assets/iee/Baker_ArcticOffshoreOil5 .pdf $>$ accessed 1 September 2015 . 
conditions, Best Available Technology (BAT) and Best Environmental Practices (BEP). To this end, the MRA (Article 55) establishes the obligation

to prevent, limit and combat pollution and other impacts on the climate from activities that may directly or indirectly: (i) Endanger human health; (ii) Damage animal or plant life or natural or cultural values on or in the soil, in the sea or in the subsoil; (iii) Obstruct the rightful utilisation of the soil, the sea, the subsoil or natural resources; (iv) Impair human conditions of life; (v) Impair recreational values or activities.

The rights granted to indigenous peoples can be explained by the special relationship, from a spiritual and material point of view, that they have with their land and territories. In the MRA, the protection of nature should take priority over the granting of operating licenses. Licenses are subordinated to the "consideration for avoiding impairment of nature and the habitats of species in designated national and international nature conservation areas and disturbance of species for which the areas have been designated" (Article 6o).

The Greenland Bureau of Minerals and Petroleum (вмР) prepares the Strategic Environmental Impact Assessment (SEIA) to identify existing gaps or to recommend specific measures of mitigation and monitoring. In turn, applicants should prepare an Environmental Impact Assessment (EIA) as well as a Social Impact Assessment (SIA). Both proceedings require the participation of the interested public before the BMP and the government of Greenland sanctioning of license applications.

Under the EIA, once the applicant identifies that an offshore hydrocarbon project has significant environmental impact, the BMP has to facilitate the exercise of the right to public participation. However, the MRA does not define the length or format that such participation should take, it only provides that an opportunity for a public hearing should be given. In addition to relying on the SEIA, the EIA is complemented with the documentation available in the National Environmental Research Institute (NERI), especially in what relates to environmental impact assessment of seismic activities in Greenland waters. ${ }^{69}$ This requirement reflects, albeit indirectly, the importance that the Greenlandic law assigns to the protection of marine mammals. The BMP

69 David Boertmann, Jakob Tougaard, Kasper Johansen, Anders Mosbech, Guidelines to environmental impact assessment of seismic activities in Greenland waters (NERI Technical Report No. 785, National Environmental Research Institute-Aarhus University, 2nd ed. 2010) <http://www2.dmu.dk/Pub/FR785.pdf > accessed 1 September 2015. 
publishes specific guidelines for the preparation of EIAs, specifically related to the exploration or exploitation of hydrocarbons on the coast of Greenland, and which take into account "present use of natural resources," including hunting, fishing, and tourism; and further requires that the "cumulative impacts with other human activities in and near the license area should be considered". 70

In the event that a project may have a significant impact on social conditions and human development, the applicant has to prepare a sIA in addition to the EIA, which must consider not only the consequences on land and resource use, the health and socio-cultural characteristics of the population, but also other factors such as the level of employment generated by the activity or degree of improvement of their socio-economic conditions. While it's clear that the MRA does not detail when or to what extent impact should be assumed by the applicant, nor does it detail the criteria for assessing such impact, it is important that the law introduces the notion of social sustainability in the development of this procedure. Thus, before the BMP grants a license to operate offshore, the applicant must engage in a process of consultation and public hearings with the population and relevant stakeholders.

However, it should be noted that even if the SIA results indicate a potential social impact, the MRA leaves the BMP with sufficient discretion to authorise the project should it deem it appropriate. Therefore, the Greenlandic government may decide that the economic benefits of a project outweigh damages arising from the socio-cultural impact generated, and grant the license. In these circumstances, the licensee and the BMP use the SIA to develop a Benefit and Impact Plan (BIP) that serves to develop and implement an Impact Benefit Agreement (IBA). In fact, this is one of the purposes of the SIA to "assist mining companies and their consultants in implementing the Impact Benefit Agreement."71 Moreover, it is worth noting that one of the main aims of the SIA is to engage all relevant stakeholders in consultations. To do so, the applicant is required to provide a "non-technical brief" before the public hearings in order to identify the issues and ensure that through the sIA concerned groups have an influence on topics to be studied by the SIA with the support

$70 \quad$ BMP Guidelines - for preparing an Environmental Impact Assessment (EIA) report for activities related to hydrocarbon exploration and exploitation offshore Greenland (Danish National Environmental Research Institute, Greenland Institute of Natural Resources and Bureau of Minerals and Petroleum, 2011) <https://www.govmin.gl/images/stories/ petroleum/BMP_EIA_Guidelines_Jan_2011.pdf > accessed 1 September 2015 .

71 Guidelines for Social Impact Assessments for mining projects in Greenland (Bureau of Minerals and Petroleum, Greenland, 2009) <https://www.govmin.gl/images/stories/ minerals/sia_guideline/sia_guidelines.pdf $>$ accessed 1 September 2015. 
of the BMP. Stakeholders may include-but are not limited to-the public sector, non-governmental organizations, affected communities, individuals and enterprises. The government itself usually provides a list of stakeholders that the applicant should consider. It is questionable however, to what extentthesestakeholders, and particularlyindigenouspeoplesactuallyfeellinked to the BMP (or more generally involved with the MRA's process), when in fact, the main interest of this organization is the extraction industry, and not the interests the affected local communities may have. While the MRA promotes procedures to involve local communities in decision making with regards to oil exploration and exploitation, one of the main criticisms of it has been the lack of transparency on those processes. This is coupled with a lack of commitment by Greenland to ratify the Aarhus Convention on Access to Information, Public Participation in Decision-making and Access to Justice in Environmental Matters. ${ }^{72}$ (Denmark's signature does not include the territory and the areas governed by the AGSG. $)^{73}$

\subsection{The Applicable Secondary EU Law}

Despite the actions of the EU institutions mentioned above, the lack of integration of indigenous peoples into specific EU policies is still significant. In fact, the biggest challenge is how to incorporate these issues into the specific measures taken by the $\mathrm{EU}$ institutions through the regular development of $\mathrm{EU}$ legislation. In this sense, it's important to point out that the relevance of the above statements is compromised when put into practice in some of the policies most affecting sustainable development of the Arctic region. A clear example is the case of offshore oil drilling in the Arctic. The EU law has so far been scarcely affected by the influence of the evolution of international law regarding the rights of indigenous peoples in the context of offshore hydrocarbons drilling and the extractive sector.

The EU Member States control hydrocarbon resources in their territories. They are also responsible for licensing the exploitation of these resources. In order to ensure that these licenses are granted in a way that is fair and

72 UN/ECE Convention of 25 June 1998, on Access to Information, Public Participation in Decision-making and Access to Justice in Environmental Matters, Aarhus, Denmark, UNTS, vol. 2161, p. 447. International Work Group for Indigenous Affairs (IWGIA), "Greenland", 2015 Yearbook <http://www.iwgia.org/images/stories/sections/regions/arctic/ documents/IW2015/Greenland_IW2015_web.pdf> accessed 1 September 2015.

73 Ibid., Declarations and reservations Upon Signature: Denmark <https://treaties.un.org/ pages $/$ ViewDetails.aspx? src $=$ TREATY\&mtdsg_no=XXVII13\&chapter $=27 \&$ lang=en\#End Dec $>$ accessed 1 September 2015 . 
transparent, national governments are obliged to follow a common set of rules. The requirements for licensing procedures of $\mathrm{EU}$ companies to be used by Member States for the prospection, exploration, and exploitation of oil and gas under their jurisdiction are laid out in the Directive 94/22/EC of the European Parliament and of the Council of 30 May 1994 on the conditions for granting and using authorizations for the prospection, exploration and production of hydrocarbons. ${ }^{74}$ This Directive ignores the participation of local populations on the process of granting those licenses. Concerning the indirect affect on their rights, the Directive merely provides in Article 4, on the delimitation of the geographical areas covered by a license, that it should be done "in such a way that it does not exceed the area justified by the best possible exercise of the activities from the technical and economic points of view"; and also that "the duration of an authorization does not exceed the period necessary to carry out the activities for which the authorization is granted." According to Article 5, the procedures for granting authorizations should be established in a transparent way on the basis of objective and non-discriminatory criteria.

In order to prevent and respond to accidents at offshore drilling oil facilities such as the 2010 Deepwater Horizon in the Gulf of Mexico, the EU adopted Directive 2013/30/EU on the Safety of Offshore Oil and Gas Operations. ${ }^{75}$ The Directive applies to the territorial sea, the EEZ and the continental shelf of Member States and Parties of the European Economic Area. The Directive mentions the Arctic in Recital $5^{2}$ to point out its vulnerability to the phenomenon of climate change and in Article 33 to demand high safety standards for offshore oil and gas extraction operations, internationally and within global and regional powers. Under Article 33, the Directive 2013/30/EU states that "the Commission shall promote high safety standards for offshore oil and gas operations at international level in relevant global and regional fora, including those relating to Arctic waters". This includes a series of mandatory actions: as,

74 [1994] oJ L164. A flexible approach to the territorial scope of EU law has been applied by the European Court of Justice when considering that "Since a Member State has sovereignty over the continental shelf adjacent to it albeit functional and limited sovereignty (...) work carried out on fixed or floating installations positioned on the continental shelf, in the context of the prospecting and/or exploitation of natural resources, is to be regarded as work carried out in the territory of that State for the purposes of applying EU (...). A Member State which takes advantage of the economic rights to prospect and/or exploit natural resources on that part of the continental shelf which is adjacent to it cannot avoid the application of the Eu law provisions", See Case C-347/10, A. Saleminkv. Raad van bestuur van het Uitvoeringsinstituut werknemersverzekeringen [2012] Digital reports (Court Reports-general) ECLI identifier: ECLI:EU:C:2012:17, par. 35 and 36. 
for EU registered companies, duties include establishing risk and emergency response plans; preparing a Major Hazard Report (MHR) for the offshore installation; keeping resources at hand in order to put them into operation when necessary; facilitating the independent verification of technical solutions concerning safety operations, and becoming fully liable for environmental damages caused to protected marine species and natural habitats. National authorities of Member States are responsible to ensure that companies are well financed and have the necessary technical expertise, and to verify safety provisions, environmental protection measures, and emergency preparedness through the setting up of national supervisory mechanisms. In addition, citizens have the right to access the information on the installations' safety.

However, Directive 2013/30/EU only covers accidental pollution related to oil or gas operations at sea, and does not directly deal with prevention of operational pollution. In case of an accident, "Member States shall require companies registered in their territory and conducting, themselves or through subsidiaries, offshore oil and gas operations outside the Union as licence holders or operators to report to them, on request, the circumstances of any major accident in which they have been involved." (Article 20.1). ${ }^{76}$ Moreover, the Directive does not apply to major accidents occurring on the high seas (except in the case of operations carried out on the continental shelf of a Member State, or in the case "where there is a risk of the foreseeable transboundary effects of major accidents affecting third countries" according to Article 31.3). ${ }^{77}$ The Directive states that Member States "shall require operators and owners to ensure that their corporate major accident prevention policy document referred to in paragraph 1 also covers their production and non-production installations outside of the Union" (Article 19.8). As a result, in this area, the Directive can be considered to have some extra-territorial effect. The absence

76 Private stakeholder companies have noted that such a duty to report major accidents, even when occurring outside the $\mathrm{EU}$ "is in contradiction to Article $20(. .$.$) which ascribes this$ duty to operators, who are the entities in overall control of offshore operations. In practical terms, it would be ineffectual to obtain a report from a contractor; in legal and contractual terms, such a requirement would probably compromise the owner in the country where the incident occurs." International Association of Drilling Contractors, "Letter on The implementation of Directive 2013/30/EU on the safety of offshore oil and gas operations addressed to the British Department of Energy and Climate Change and the Health and Safety Executive" (Department of Energy \& Climate Change and Health \& Safety Executive 2014) <http://www.iadc.org/wp-content/uploads/2014/o2/IADC-response-toUK-CD-272-.pdf > accessed 1 September 2015.

77 Jose Juste Ruiz, "La directive européenne sur la securité des opérations petrolières et gazières en mer", (2014) 23 (1) Revue juridique de l'Environnement 28. 
of any mention of indigenous peoples or local communities in the procedures for granting exploitation concessions is particularly striking. In fact, the obligations included in the Directive regarding their participation are scarce and limited to Article 5 which requires that competent authorities "have previously ensured that early and effective public participation on the possible effects of planned offshore oil and gas operations on the environment pursuant to other Union legal acts, in particular Directive 2001/42/EC or 2011/92/EU as appropriate, has been undertaken." If this has not happened, Member States should ensure that "a) the public is informed (...); c) relevant information about such planned operations is made available to the public (...); d) the public is entitled to express comments and opinions at a time when all options are open before decisions to allow exploration are taken".

In spite of the fact that there is a specific mention of Directive 2001/42/EC of the European Parliament and of the Council of 27 June 2001 on the assessment of the effects of certain plans and programmes on environment ${ }^{78}$ and of Directive 2011/92/EU of the European Parliament and of the Council of 13 December 2011 on assessment of the effects of certain public and private projects on environment, ${ }^{79}$ as amended by Directive 2014/52/EU of 16 April $2014,{ }^{80}$ none of these rules apply to the territory of Greenland. ${ }^{81}$

\section{How a Strengthened EU-Greenland Relationship Contributes to the EU's Policy Objectives in the Arctic}

With limited population, Greenland's main challenge is managing a vast territory rich in natural and mineral resources, which attracts the interest of some major world powers. In turn, the main challenge of the EU is strengthening its role as part of the inner circle of Arctic governance. To do so, it has to consider its relationships with and its presence in the Arctic strategically. In such a

\footnotetext{
78 [2001] OJ L197.

79 [2014] OJ L26.

80 [2014] oJ L124.

81 The same is true regarding the Directive 2004/35/EC on Environmental Liability, which addresses the liability for damage caused to the environment, including those caused by offshore installations; the Directive 85/337/EEC on Environmental Assessment, as amended by Directives 97/11/EC, 2003/35/EC and 2009/31/EC, which harmonises the principles of environmental impact assessments of projects; the Waste Framework Directive 2008/98/EC; or the Directive 92/91/EEC on health and safety of workers in the mineralextracting industries through drilling.
} 
context, an enhanced cooperation between Greenland and the EU has mutual benefit.

Firstly, the governance system of the Arctic has traditionally been characterised by the predominance of, in particular, the five coastal States of the Arctic Ocean. The core of the Arctic cooperation has traditionally been identified with the "Arctic Five". Greenland, as part of the "Arctic Five", thanks to certain Danish benevolence, is a unique case in that context. Beyond its role as one of the "Arctic Five", the Greenlandic sub-delegation takes the floor with its own representative in the Arctic Council meetings, though the national delegation is led by Denmark. Greenland is also very proactive in other Arctic fora. It is represented at the Conference of Arctic Parliamentarians, jointly with the representatives of the Arctic Council Member States and the representatives of the European Parliament. Greenland could therefore contribute to further involving the EU in the Arctic governance system.

Secondly, without being a sovereign State, Greenland is a territory that is directly responsible for many key areas related to the development of the Arctic. It is legally bound to a Member State of the EU as an autonomous territory. This situation could see future developments such as Greenland's independence from Denmark or even a possible (re)joining of the Eu. ${ }^{82}$ If Greenland becomes independent, it is very important for the EU to ensure it has a strong domestic economy. A politically independent but economically dependant Greenland would imply risk for the development of the whole Arctic region. This is because of the interest that some non-Arctic stakeholders have in the region's natural and mineral resources and the risk of them being capable of 'informally' driving Greenland's natural resources management policy. The EU assumes its role as an economic "safety net" for Greenland and defends a strong relationship that allows the $\mathrm{EU}$ and Greenland to jointly tackle global challenges in the management of the Arctic. On the one hand the EU is committed to promoting the development of Greenland, in particular, the diversification of its economy on the basis of a resources management policy which is environmentally, socially and financially sustainable; on the other hand, it demands Greenland considers the potential role it may have as supplier of strategic raw materials for the EU, according to the principles of free trade.

82 In that sense Damien Degeorges, The role of Greenland in the Arctic, n. 4 above and André Gattolin, Rapport d'information fait au nom de la commission des affaires européennes sur l'avenir du Groenland, (Sénat française, session ordinaire de 2014-2015, $\mathrm{N}^{\circ} 152,2014$ ) <http://www.ladocumentationfrancaise.fr/rapports-publics/144000755/> accessed 1 September 2015 . 
Thirdly, the identity of Greenland is closely linked to indigenous peoples of the Arctic, who are neither part of the "Arctic Five" nor Members of the Arctic Council (though they have the status as Permanent Participants). The role of Greenland as ambassador for Arctic indigenous peoples before regional and international fora is obvious. In that context, the EU has had a significant evolution from the perspective of traditional human rights, to a mainstreaming approach towards indigenous peoples' rights. Notwithstanding, it should be pointed out that on the EU's side there is still room for greater coherence and consistency. It has been shown that the EU lacks mechanisms to guarantee the participation of local communities in the decision-making process concerning offshore oil drilling operations. It is also worth mentioning some historical institutional miscommunications between representatives of Arctic indigenous peoples and the EU institutions. Although there are international legal instruments that are potentially applicable to prevent or alleviate the adverse impact on communities and the environment of Greenland's offshore hydrocarbon activities, the CJEU has given a very restrictive interpretation to the UNDRIP or the No. 169 of the ILO Convention. For this reason, it is essential to avoid any hint of condescension by the EU actions that may affect Greenland and the Arctic indigenous peoples. Two examples may illustrate to what extent certain aspects require more attention by the EU.

The first relates to the EU ban of seal products in the EU market, established under the Regulation (EC) No 1007/2009 of 16 September 2009, on trade in seal products. ${ }^{83}$ Seal hunting is highly integrated in Greenlandic traditions. Although it is directly linked to the subsistence of indigenous communities, it is usually carried out on a bigger scale and has a considerable commercial component. Regulation (EC) No 1007/2009 established an exception that relates to the commercialisation of seal products captured specifically by indigenous communities, which entered into force in $2013 .{ }^{84}$ When the exception came into force, the Greenlandic authority was already prepared to implement the certification system required by the Regulation. It almost immediately got acceptance by the EU as an authorised body to issue certificates

83 [2009] OJ L286, 36. This has been amended by Regulation (EU) 2015/1775 amending Regulation (EC) No 1007/2009 on trade in seal products and repealing Commission Regulation (EU) No 737/2010, [2015] OJ L262 and Commission Implementing Regulation (EU) of 13 October 2015 laying down detailed rules for the implementation of Regulation (EC) 1007/2009 on trade on seal products, [2015] OJ L271.

84 [2010] OJ L216, 1. 
for seal products. ${ }^{85}$ With this, the Inuit communities of Greenland became at that time the only indigenous communities benefiting from the exception of the regulation, unlike the Canadian Inuit communities. The ban was finally amended in 2015 in order to reflect the wTo ruling of 22 May 2014. ${ }^{86}$ However, in spite of that change and although exports from seal products are becoming less important to the economy of Greenland, there is still a general feeling on the part of the Greenlandic population that the Greenland's lifestyle and traditions continue to be misunderstood by the $\mathrm{EU}$.

Whaling is another sensitive issue in the relationship between Greenland and the EU. According the International Convention for the Regulation of Whaling the number of whales killed under the Aboriginal Subsistence Whaling (ASW) provision must align with subsistence needs. ${ }^{87}$ Greenland, like other traditional whaling countries in the region (Norway or Iceland), is in favour of increasing the number of whale species for which hunting is permitted by the International Whaling Commission (IWC). This policy often clashes with the more conservationist EU perspective, which supports the setting of catch limits for ASW in certain conditions and the 1986 moratorium on commercial whaling. This has caused some confrontations in IWC meetings, in which Denmark representing the interests of Greenland and Faroe Islands ${ }^{88}$

85 See, Commission Decision of 25 April 2013, recognizing the Greenland Department of Fisheries, Hunting and Agriculture for the purposes of Article 6 of Commission Regulation (EU) 737/2010 of 10 August 2010 laying down detailed rules for the implementation of Regulation /EC) 1007/2009 on trade in seal products, C(2013)2277 final; and Commission Decision of 26 October 2015, recognizing the Greenland Department of Fisheries, Hunting and Agriculture in accordance with Article 3 of Implementing Regulation (EU) 2015/1850 laying down detailed rules for the implementation of Regulation /EC) 1007/2009 on trade in seal products, $\mathrm{C}(2015) 7274$ final.

86 WT/DS-EU-Measures prohibiting the Importation and Marketing of Seal Products <https://www.wto.org/english/tratop_e/dispu_e/cases_e/ds40o_e.htm> accessed 1o March 2017. See also Commission decision (EU) 2017/265 of 14 February 2017 including the Government of Northwest Territories of Canada as a recognized body in the list referred to in Article 3 of Implementing Regulation (EU) 2015/1850 laying down detailed rules for the implementation of Regulation (EC) 1007/2009on trade in seal products, C (2017) 757, [2017] OJ L39.

87 International Convention for the Regulation of Whaling [1946], 161 UNTS 72, Art. I (Schedule). See also IWC, Aboriginal / Subsistence Whaling (with opened reference to the Alaska and Greenland Fisheries) (1982) and IWC White Paper on Management and Utilization of Large Whales in Greenland, (2013), IWC/64/Asw 8, $2012<$ https://archive.iwc .int/pages/search.php?search=!collection84> accessed 30 November 2016.

88 Final Act of the Intergovernmental Conference (IGC), which agreed the Treaty on European Union (1992), Declaration $\mathrm{N}^{\circ} 25$. 
in international negotiations, had to reject common positions adopted by the EU. For example, the IWC rejected Denmark's proposal to increase Greenland's ASW quota in 2008, on the grounds that an increasing commercial use was being made of the catches. ${ }^{89}$ Confrontations were intensified in July 2012, when the IWC rejected again a new proposal to increase the Greenland's Asw catch limit. ${ }^{90}$ Following this refusal, in 2013 Denmark threatened to withdraw from the IWC if it did not adopt a more flexible position regarding Greenland. ${ }^{91}$ A compromise finally has been made, not without difficulties, between the opposing views of the EU and the Danish/Greenlandic authorities. Denmark succeeded at the September 2014 IWC meeting, and its proposed catch limits were approved with the backing of the EU.92

Final Remarks

Greenland is an important gateway to the Arctic for the EU and plays a bridging role as an EU partner. On the one hand, still bound to one of the EU Member States, it has a proactive role in distinct Arctic fora; on the other hand, while being granted the status of ост, it has a strong relationship with the EU based on a partnership agreement which partially provides for its social and economic development.

One of the key elements of this relationship is the legitimacy that must necessarily support the EU's action with regard to the Inuit community of Greenland. Therefore, this legitimacy must be built within the framework

89 IWC, Annual Report of the International Whaling Commission 2009 (2010), $22<\mathrm{https} / / /$ archive.iwc.int/pages/view.php?ref=64\&search=!collection2\&order_by=relevance\&sort= DESC\&offset $=0$ \& archive $=0 \& k=\&$ curpos $=4>$ accessed 1 September 2015 .

9o IWC, Annual Report of the International Whaling Commission 2012 (2013), $15<$ https:// archive.iwc.int/pages/terms.php?ref=67\&search=!collection2\&k=\&url=pages $\% 2$ Fdown load_progress.php $\%{ }_{3}$ Fref\% $\% 3$ D67\%26size $\%{ }_{3} \mathrm{D} \% 26$ ext $\%{ }_{3}$ Dpdf $\% 26 \mathrm{k} \%{ }_{3} \mathrm{D} \% 26$ search $\%$ ${ }_{3} \mathrm{D} \% 2521$ collection2\%26offset\%3 Do\%26archive\%3Do\%26sort\%3DDESC\%26order by\% ${ }_{3}$ Drelevance $>$ accessed 1 September 2015 .

91 Chair's Report of the 2013 IWC Bureau Meeting, $3-4$ September 2013, $4-5<\mathrm{https}$ ://archive .iwc.int/pages/view.php? $r e f=1797 \&$ search $=a s w \% 2 \mathrm{C}+2013 \% 2 \mathrm{C}+$ greenland $\% 2 \mathrm{C}+$ year $\%$ 3 A2013\&order_by=relevance\&sort=DESC\&offset $=0$ \&archive $=0 \& \mathrm{k}=\&$ curpos $=1>$ accessed 1 September 2015 .

92 IWC/65/ASWo2, 65th Meeting of the International Whaling Commission, Aboriginal Subsistence Whaling Sub-Committee <https://archive.iwc.int/pages/view.php?ref=3539 \&search $=$ !collection98\&order_by=relevance\&sort $=$ DESC\&offset $=0 \&$ archive $=0 \& \mathrm{k}=\&$ cur pos $=1>$ accessed 1 September 2015 . 
of respect for the rights of indigenous peoples and local communities, an element that should provide the $\mathrm{EU}$ with better possibilities to interact into the Arctic scenario.

Unfortunately, however, the current legal EU framework does not guarantee a full commitment with Arctic indigenous peoples. From the EU point of view, protection of the Arctic local communities continues to be an area to be further developed as it still lacks effective mechanisms to guarantee their participation in the decision-making processs related to the exploitation of hydrocarbon resources. The study of EU regulation on oil and gas offshore extraction identified the limitations of their participation in the decision-making process and the right to be consulted through their representatives.

In the short and medium term, the EU should continue to have an essential role to enhance the diversification of Greenland's economy. In the long term, though difficulties for Greenland's independence do exist, new opportunities may appear in the EU-Greenland relationship, such as Greenland being considered as a third State or even Greenland's accession to the EU. In this situation, the EU will be critical for Greenland to secure a sustainable economy. This is especially true in the context in which some other non-Arctic powers, such as China, have shown a much more pragmatic approach in their interest in Greenland. In turn, this vested economic contribution from the EU could result in reinforcing the EU's political links with the island, and consequently, the EU presence in the Arctic. Playing a stronger and more constructive role in effectively helping solve the region-specific challenges related to meaningful participation with local and indigenous peoples will also give the EU the opportunity to increase collaboration with other Arctic and non-Arctic interested players. 